\title{
40. Indie game localization communities as spheres of interaction
}

\section{Selahattin KARAGÖZ ${ }^{1}$}

APA: Karagöz, S. (2021). Indie game localization communities as spheres of interaction. RumeliDE Dil ve Edebiyat Araştırmaları Dergisi, (Ö9), 492-505. DOI: 10.29000/rumelide.981570.

\begin{abstract}
An Indie game may be described as a game developed by a single person or by a rather smaller community often with a minimal budget. An indie games becomes be more visible on the market and accesses a wider audience through localization, however, the developers generally allocate minimal budgets (if available) for the localization practices and they tend to depend on fan - volunteer localization practices or low-budget localization by freelancers. Online communities of indie game localization bring developers who tend to make use of "free" or "cheaper" labour and translators of fan or volunteer localization communities who wish to attend a career in localization industry, freelancers, smaller localization or translation agencies together and serve as a medium of interaction. The analysis of interaction and exchange, the nature of the communities would provide insight into the abovementioned field of exchange. This paper aims to trace the footprints of "agents" through their profiles, posts, discussions and and produced content on the web with a specific focus on Indie Game Localization Facebook Page and based on the data gathered, to define the limits of online community, to describe nature of the agents and to draw the borders of the "online" mutual relationship among translators, translator candidates, localization agencies and gama developers
\end{abstract}

Keywords: Online communities, indie game localization, online interaction

\section{Etkileșim alanları olarak bağımsız oyun yerelleștirme toplulukları}

\section{Öz}

Bağımsız video oyun, küçük gruplar tarafından geliştirilen çoğu zaman düşük bütçeli olan oyunları ifade eder. Bu oyunlar uygulama marketlerde görünür olmak ve daha geniş oyuncu kitlesine ulaşabilmek adına yerelleştirme uygulamalarına ihtiyaç duyar, ancak, bu uygulamaya ayırabilecekleri bütçe genellikle sınırlıdır ya da mevcut değildir. Bu bağlamda hayran yerelleștirme pratiklerine, gönüllü yerelleştirme pratiklerine ya da düşük ücretli yerelleștirme pratiklerine yönelirler. Bağımsız oyun geliştiricilere yönelik topluluk sayfaları da düşük ücretli ya da ücretsiz emek arayıșındaki geliştiriciler ile gönüllülük temelli çeviri yapan, hayran topluluklarında çeviri yapan çevirmenler, serbest çevirmenler, küçük yerelleştirme işletmelerini bir araya getiren etkileşim alanları olarak işlev görür. Bu alanlarda gerçekleşen etkileşimin irdelenmesi bu mübadele alanına üst bakış sunacaktır. Bu bağlamda bu çalışma, ağ üzerinde Indie Game Localization Group sayfası özelinde katılımcıların profilleri, gönderileri, tartışma ve paylaşımlara katılımlarının izini sürmeyi, elde edilen veri ışığında bağımsız oyun dağıtımında yerelleştirme alanını bir mübadele olanı olarak betimlemeyi, benzer nitelikteki çevrimiçi toplulukların sınırlarını çizmeyi, eyleyenlerin niteliklerini betimlemeyi ve nihayetinde çevirmen, aday çevirmen, yerelleştirme işletmesi ve geliştiriciler arasındaki çevrimiçi ilişkiyi açlklamayı hedeflemektedir .

1 Dr. Arș. Gör., Ege Ünversitesi, Edebiyat Fakültesi, Mütercim Tercümanlık Bölümü, (İzmir, Türkiye) selahattin.karagoz.akd@gmail.com, ORCID ID: 0000-0002-9257-8197 [Araștırma makalesi, Makale kayıt tarihi: 26.07.2021kabul tarihi: 20.08.2021; DOI: 10.29000/rumelide.981570]

Adres | Address

RumeliDE Dil ve Edebiyat Araşturmaları Dergisi Osmanağa Mahallesi, Mürver Çiçeği Sokak, No:14/8 Kadıköy - ISTANBUL / TÜRKIYE 34714 e-posta: editor@rumelide.com tel: +90 $5057958124,+902167730616$

RumeliDE Journal of Language and Literature Studies

Osmanağa Mahallesi, Mürver Çiçeği Sokak, No:14/8

Kadıköy - ISTANBUL / TURKEY 34714

e-mail: editor@rumelide.com

phone: +90 5057958124 , +90 2167730616 
Anahtar kelimeler: Çevrimiçi topluluklar, bağımsız oyun yerelleştirme, çevrimiçi etkileşim

\section{Introduction}

This paper aims to discuss the nature of interaction in indie game localization communities, to describe the agents and institutions involved in such interaction and accordingly to depict a vivid picture of the communities attached to the localization and game development industries. Within this scope, the nature of the relationship between indie games and online communities are to be described, then the concept "online community" shall be discussed in detail; finally, the nature of indie game localization communities and interaction within the communities shall be described critically.

Localization of the indie video games is relatively underresearched. Current literature essentially covers Consalvo's pivotal work on participatory role of the fans in indie game localization (2012), the fieldwork oriented analysis of the role of localization in indie game production by Toftedahl, Backlund, Engström (2018) and the detailed analysis of the factors in indie game localization by Berthouzoz (2019). The relationship between communities of indie game localization sphere, which is the focus of this paper, is yet to be observed from an academic perspective.

An investigation into the nature of indie game localization communities would be constructed on the following research questions: "Why do indie game developers join indie game localization communities?" "What can the nature of indie game localization communities tell us about localization process?". A survey into the discussions on the definition and nature of the indie videogames would be an initial step to answer such questions.

Independent - or indie - video games are often "referred to as a relatively new area of both game development and game studies" ( Berthouzoz, 2019, 15), so, there is no consensus on the definitions and discussions.

As game researcher Simon (2013) observes, "there is no point in seeking a formal definition or classification of 'indie games' any more than it has helped us to try to define 'video games... the best we can do is follow, articulate, and perhaps join in with, other actors' attempts to do work with the concept" (2). This paper is not to discuss definitions of indie game in detail, thus, the scholarly and practitioner oriented perception attempts to define or to frame "indie video game" shall be briefly summarized to define the unique relationship between the communities and indie video games as Simon pointed out.

Various researchers have ventured to define or describe indie video games. For instance, Lipkin (2013) compares mainstream with indie games in "the contrast between whatever it is and whatever 'indie' is", he accordingly defines "indie" in contrast to the "mainstream or AAA games" and game development. He claims that "the mainstream is characterized as emphasizing profit and popularity over creativity and artistry." (9- 11). Martin and Deuze (2009), on the other hand, focus on the structure of indie game development and underline the role of digital distribution in indie game development. According to them, "the multiplication of avenues for (digital) game distribution lend themselves toward much smaller scale (or even individual), artist-driven type of authorship that resonates with the beginnings of game development, where production was dominated by hobbyist, fan, artist, and amateur mentalities." (279). Freeman and Macneese (2019) rather focus their lenses on the structure of indie development teams and note that "...teams, which often consist of freelancer developers, artists, or non-professional technology users, tend to be small but are strongly interest-driven (e.g., online strangers with a shared interest in

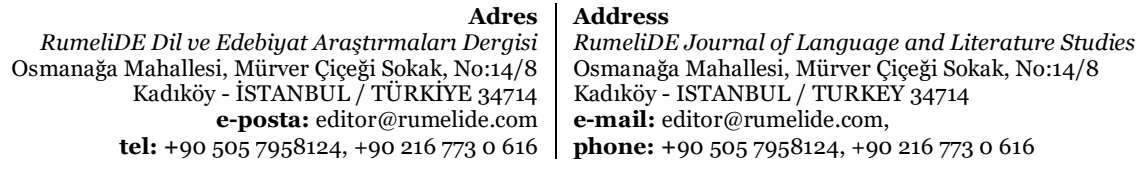


gaming and making games) and highly task-oriented (e.g., developing a sophisticated software product)" (724).

Czarnota (2018) takes a closer look at the nature of indie games as product and observes that "because of the limited budget, indie studios cannot develop photorealistic graphics or complex videogames that would captivate the mass market, just like the big-budget videogames do. Instead, those small developers seek to attract a market niche by offering products that are unique."(57). Fiadotao's (2018) definition is product oriented. An indie game, in his words, "is a game created by an independent team of developers, typically with limited resources, without a publisher or with no significant involvement in the artistic"process on the publisher's part.".

Game researcher Ruffino (2013) lists the pecularities of indie game development. According to Ruffino, an indie game may be identified as a game "produced by a single person or a small group without aid of the publisher.". He also notes that "the phenomenon of independent games cannot be explained solely in terms of a business model. This is because not only are there numerous cases of games with no commercial purpose, but also because independent games are enriched, in the ways they are described and narrated, by other, non-financial values." (107). Garda and Grabarczyk (2016) focus on concepts of independence and define three types of independence as "financial, creative and publishing which are although related, are autonomous". Gurvara-Villalobos (2013) also notes that "in order to fulfil their goal as independent developers, studios need to play with neo-fordist strategies of global capitalism, leaning on flexible labour, constant re-skilling, and work fragmentation as a means to keep competitiveness and to some extent, creative control."(1).

The definitions with a focus on the concept of independence, the structure of indie games, indie game production or labour choices given above illustrate various perspective of the indie game. Despite numerous perspectives they shed light on, they share common traits as well. Above all, according to the current literature, an indie game may be defined as a game developed with limited human and/or financial resources. The limited financial resources drive the developers to find alternative pathways. The lack of financial capital is something definitive in localization practices which sets indie game localization unique as well which is also underlined by the practitioners. The developers (the practitioners) often point out to the "lack of financial resources" in game localization.

A member of Jumb-o-Fun, a small indie development team, notes that "they have always felt it was important for maximizing revenue... on the other hand, they were never sure if it would be worth the cost, unless they had a very successful game." (Yoccoz, 2017) while Mega Dwarf, a three team developer team (Yoccoz, 2017) also claims "before they localized their game, they weren't really sure if it would be worth it....for a lot of indie developers, the cost of localizing a game professionally isn't something they can afford."

The lack of financial capital in indie game localization is observed by research circles as well. According to Toftedahl, Backlund and Engström (2018), the lack of resources is "another factor of interest forcing the developers find new and creative ways of translating their games" (14).

O'Hagan and Chandler (2016) on the other hand, underline the importance of budget in localization practices in indie video games:

"From a budget standpoint, smaller game teams are constrained as to what localization services they can afford. If they are able to get something translated, they may not then be able to afford linguistic checks... The development team will send out a call to the indie gaming community and ask for volunteers to help

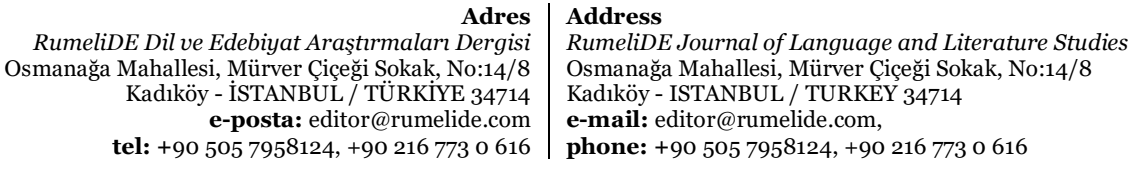


translate the game. This type of work is especially appealing to students who are looking to build up a game translation portfolio."(317)

According to Berthouzoz (2019), "game characteristics, game development and localization process, feedback received on the game and game pricing and funding may be the factors in the number of localized versions and level of localization in indie games". She (2019) also declares that "fan translators often play a huge role in indie game localization" (56) and "the localization of indie games examined in her study was mostly carried out by fans or by acquaintances of the developers, presumably for free or at little cost" (112).

As practitioners and researchers observe, the budget-friendly or free localization may be the creative pathways of indie game localization. The abovementioned search for the cheaper or free labour by developers and the desire of students or amateurs to build up their portfolio lead to the formation of virtual - online spaces where the parties can gather.

This paper aims to investigate a unique case of "virtual spaces" where indie game developers, translators and other agents gather and negotiate.

\section{Online communities}

The virtual spaces bring people with common interests, common drives or common knowledge together. As underlined in the Introduction, indie game developers have limited access to or funding for localization services, accordingly they may require alternative spaces to interact with "free or cheaper labour". Online communities organized on a virtual environment provide spaces of exchange for developers and freelancers in this context. Research on the nature of such a space and the interaction in virtual spaces may provide insight into the agents, the processes or the drives of agents and the institutions participating in indie game localization process. The communities organized online serve as spaces of gathering, information exchange, sharing or collective actions - practices.

In 1998, Alan, Sridar and Vijaya (1998) had declared "within a year, most organizations will realize that the Web is not only a means of electronic publishing but a way to build and maintain virtual organizations and communities." (86). Currently, virtual communities are an essential part of daily life and practices of the age which is enabled by the Internet. As Postigo (2010) observes "the Internet has supported the transformative proliferation of electronic communities: Listservs, forums, chat rooms and MUDs have all contributed to an ever-increasing number of virtual places where people can come together online and discuss the issues that concern them." (599)

The above listed virtual communities may be defined accordingly as "designed communities using current networked technology, whereas communities of practice emerge within the designed community via the ways their participants use the designed community." (Johnson, 2001, 45). To investigate the interaction in virtual communities, the nature and patterns of virtual communities which define the interaction shall be discussed briefly.

There is a vast literature on virtual communities, their structure and their peculiarities. According to Porter (2004), "the literature suggests that five attributes could be used to characterize virtual communities: (1) Purpose, (2) Place, (3) Platform, (4) Population Interaction Structure, and (5) Profit Model”.

Among others, some of the research stand out for the purposes of this paper which focuses on "Population Interaction Structure".

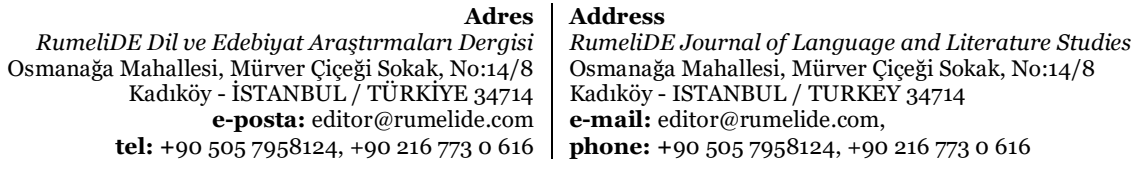


One of the pivotal works in this perspective is the one by Dickinson. Dickinson focuses on knowledge sharing in cyberspace. Dickinson (2002) claims that "the concept of community is diverse and includes social, organisational, business and knowledge communities. These can be either real-life or virtual interactions in cyberspace." (458). According to Dickinson, "a virtual community is not the actual site were people meet, but the people who meet there." (460). On the other hand, Driskell and Lyon (2002) compare internet relationships with the spatial relationships and they claim that "internet relationships are highly segmented and are usually based on shared interest rather than the more holistic relationships based on family, neighborhood, or work relationships." (382).

The relationship between online communities and real word is framed as well by academic circles. According to Wellman and Gulia (1999) , "although sending material goods over the ether is not possible, The Net supports arrangements to supply goods as well as services" (347). Online or virtual communities are closely tied with the offline world accordingly. Online communities interact with real life practices. Thus analysis of the nature of interaction online may provide insight into the localization practices in indie game industry.

Typology of online communities has also been studied from various perspectives. Armstrong and Hagel (2000) focus their lenses on four types of electronic communities and note that "communities of transaction that facilitate the buying and selling of goods and services and provide information about these transactions; communities of Interest that bring together participants who interact extensively about specific topics of interest; communities of fantasy that allow participants to create new personalities and communities of relationship that center on intense personal experiences."(85)

The classification offered by Stanoevska-Slabeva is among the most influential. Stanoevska-Slabeva (2002) offers four types of communities "discussion or conversation communities, satisfying the need for communication, task- and goal-oriented communities, satisfying the need for cooperative achievements of goals, virtual worlds, satisfying the need for fantasy and playing. hybrid communities integrating several of the types mentioned above." (78)

Mesch (2008) defines the functions of the online communities as information exchange and social support (232-235). Burnett (2000) focuses on information exchange in virtual communities, defining behaviour within communities as "non-interactive and interactive", later to define interactive behaviour as "hostile interactive behaviours, and collaborative or positive interactive behaviours".

Hostile behaviours cover "flames, trolling, spam, cyber rape" while collaborative behaviours cover "the exchange of pleasantries, gossip, and jokes, through active emotional support, to more explicitly information-oriented exchanges, including announcements, queries and requests for information, and replies to such queries and requests." (Burnett and Buerkle, 2004).

This paper deems "Indie Game Localization Group" as an online community which is constructed on the flow of information exchange among members - translators, indie game developers and translator candidates-. The community is based on the shared interest (localization of indie games) of the participants. The community is highly tied to the offline world where the games are localized, freelancers are hired or amateurs build up their portfolio and the community is a unique medium of exchange and cooperation. Monitoring and analysis of interaction in such as sphere may provide insight into complex nature of indie game localization process.

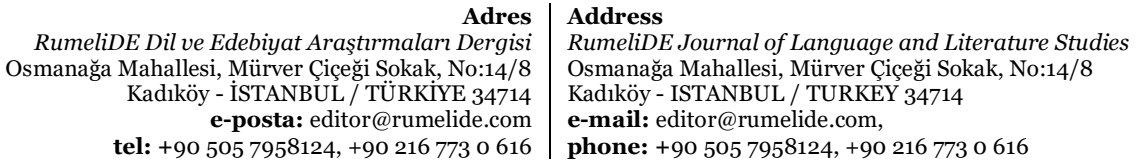




\section{Methodology}

This research is based on analysis of the data gathered through netnography. According to Howard and Mawyer (2015) "nearly unimaginable quantities of intimate, highly salient, and revelatory data made available by SM and social networking sites (SNSs) and made accessible (sortable, manipulable, transposable) via search mechanisms." (6). This abundant data may be instrumentalized to describe the structure of the community and the interaction between the members, industry, the experts which require utmost meticulous data tracing, gathering, processing ensured by "nethnography".

Netnography is defined as "participant observational research based in online fieldwork"(Kozinets, 2010, 60). Netnography is a useful tool to collect, refine and analyze the abundant data available online for translation research. The outline provided by Kozinets on the selection of medium and content, the planning phase and the scale of the research, research practice and ethics, representation and evaluation pave the path for research on virtual communities. Quantitative and qualitative data in hybrid sphere between private and public may be meticulously collected and condensed to represent the nature of interaction accordingly in line with principles offered by netnography.

Netnography oriented fieldwork have previously been conducted within scope of a few research projects. (Süter Görgüler, 2016) (Karagöz, Bogenç Demirel, 2019) (Karagöz, 2019) (Afzali \&Zahiri, 2021). According to Mangiron (2018), "netnographic approaches have also been overlooked to date, even though an important amount of information on game localisation is available on specialised websites, blogs, and Internet forums, where professionals, game critics and reviewers, as well as players and fan translators, use the Internet as the main medium for expressing their views and communicating with each other."(89).

This relatively unpopular methodology in Translation Studies may provide tools for research on communities abovementioned as an approach "primarily concerned with online communication as a source of data to form an understanding of a cultural phenomenon." (Jong).

For the purposes of this paper, netnographic fieldwork has been conducted in Indie Game Localization Facebook Group for a six-month-period. Accordingly, 163 posts by the community members have been collected, categorized and anonymized. The posts are categorized according to date, the identity of the member posted, the content - issue and details. Later the content is analyzed and proper tags have been selected to categorize the data available.

The identities of the members are tagged as TR (translator), TRC (translator candidate), RES (reseracher), LOC (Localization Agency) and DEV (Indie Game Developer). Content assesed as Issue - Content is tagged as FL (Search for Freelancer), J (Search for paid position), TST (Search for tester), FREE( Search for free labour), LEG (Search for legal issues), TEC (Search for technical issues), EXP (Offering free help for experience), PROMO (Promoting content).

The classification of the posts are conducted pursuant to the model by Burnett, focusing on interactive behaviour as netnography focuses on traces of the active participation and content creation on the web.

\section{Indie game localization community}

Indie Game Localization is an online community organized as a Facebook group. The groups founded in 2014, has 4,668 members and serves as an active community with an avarage 4 daily posts.

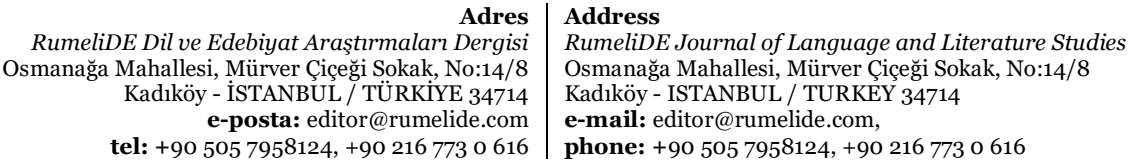


The community is promoted as "a group to help and get help with your indie game localization needs." (Indie Game Localization). The group identifies its scope as "to promote your services or help and get help for free." (Indie Game Localization) which self- define the structure of the community and the interaction within the community. The community is a proper space for a research project as it has a open participation policy, it is based on the indie game content, its members have actively been creating content and the community members have strong ties to the localization industry.

As indicated previously, netnography oriented research was conducted within the community. The fieldwork covers monitoring the group for six month period ( January 2021 - July 2021), collecting posts, anonymizing the material and analysis of the data.

The frequency of the posts classified according to the community members is given in Figure 1.

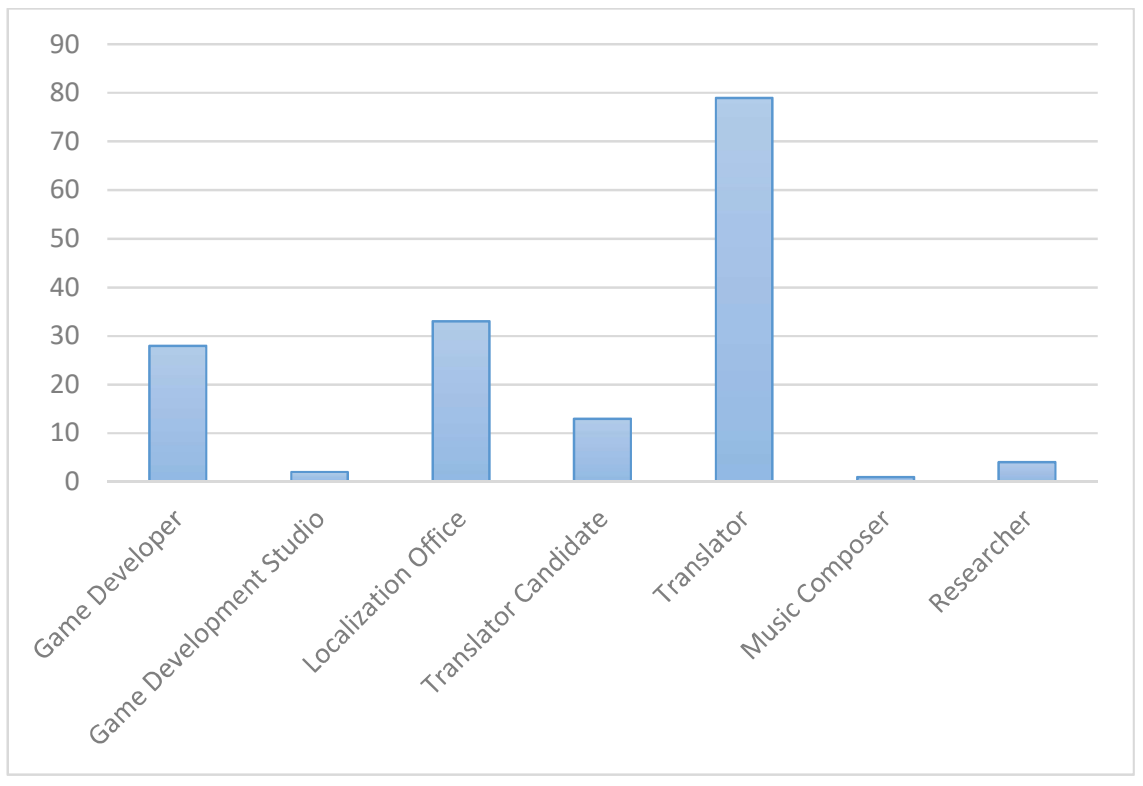

Figure 1 The frequency of the posts according to the the identity of the community members

Adres

RumeliDE Dil ve Edebiyat Araştırmaları Dergisi Osmanağa Mahallesi, Mürver Çiçeği Sokak, No:14/8 Kadıköy - ISTANBUL / TÜRKIYE 34714 e-posta: editor@rumelide.com tel: +90 505 7958124, +90 2167730616
Address

RumeliDE Journal of Language and Literature Studies Osmanağa Mahallesi, Mürver Çiçeği Sokak, No:14/8

Kadıköy - ISTANBUL / TURKEY 34714

e-mail: editor@rumelide.com,

phone: +90 5057958124 , +90 2167730616 


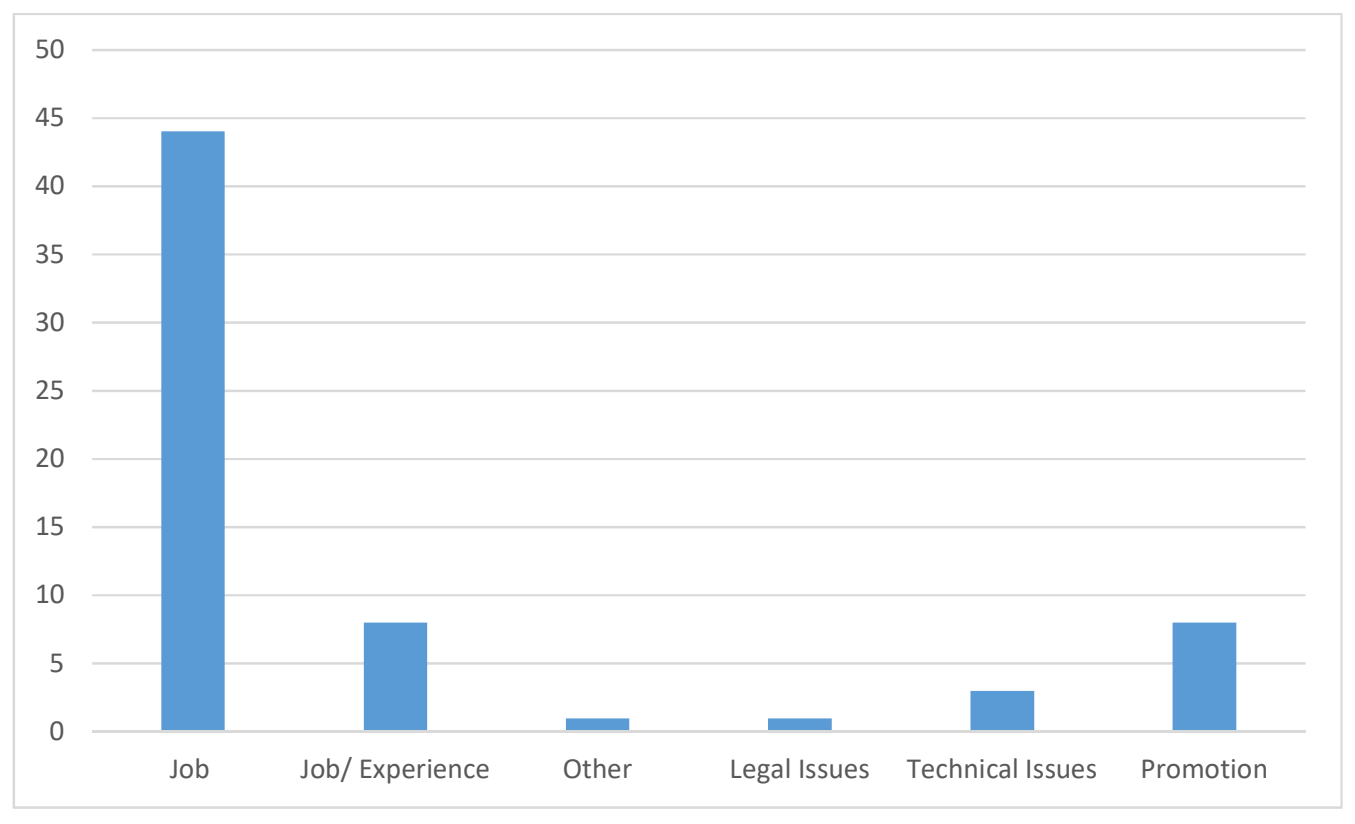

Figure 2 The posts by translators classified according to content

As the Figure 1 indicates, the majority of the posts are generated by the translators. According to analysis of the content and the structure of the posts (Figure 2), it is clear that the translators use the platform mainly as "a platform for job search". Only a few translators use the platform to promote their podcasts on localization, to search for solutions to the technical problems or legal issues or to search for a project to enrich their CV.

The content of the posts by translators is rather interesting. The translators list language pairs they can translate between, they articulate "their passion for the gaming" or their educational background; they list the previous projects they participated (if any); they give their webpages or social media account pages. Their posts are decorated with emotion-packed words attributed to their interest in gaming. For instance, TR7 marks " he would really appreciate if anyone could give him a chance and guide him along." while TR 11 underlines her desire to enrich her portfolio before working with larger scale localization agencies "before applying to the proper companies she wanted to gain some video game translation experience so she thought this group might a good start.". In rare cases, translators point out their skill set. For instancei, TR 19 marks that "he used to be what they call a one army man for a local indie game company. He illustrated, animated, and translated their games.".

Translator often highlight their personal gaming history or gaming preferences as well. For instance TR2 underlines his interest in gaming "I don't really mind the genre of the game, I deeply enjoy playing videogames so any game will work for me." while TR13 points outs to her history of gaming and notes that "she has been playing videogames since she was a little girl so she wants to become a full-time videogame localizer.".

Listing the previous work experience based on game genre is common as well. TR 13 writes that "for now, he has translated casual and idle games, RPGs, simulations, and strategies.".

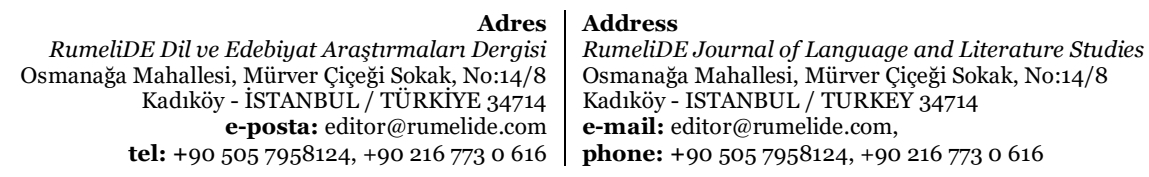




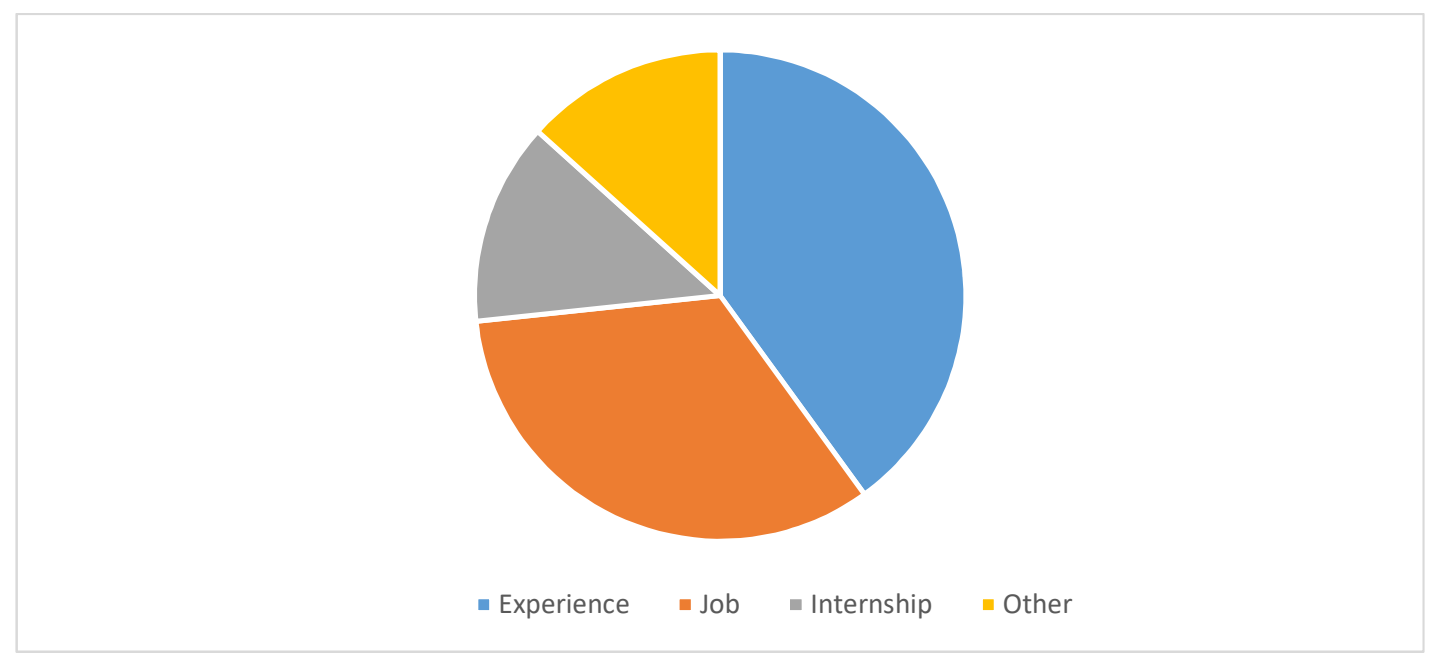

Figure 3 The posts by translator candidates classified according to content

According to Figure 3, "Translator candidates", the enthusiasts and students to have a career in localization industry create posts in the community as well. Analysis of the content of the post indicate that a vast majority of TCs are to offer "free labour" to gain experience or to build up their portfolio. Marking "their will" to contribute to the projects for free is a common practice.

For instance, TRC 7 notes "he will translate any game no matter the genre - and compelely free of charge". TRC 14 underlines that his translation is not of low quality and writes that "she is willing to work for a really small amount or even for free, but that doesn't mean that her translations are of low quality." TR1 marks "he is trying to start off with some experience in the field, not really looking for a hard profit off this hobby of his".

There are translator candidates with various education or occupation background. For instance TRC 4 holds a masters degree in TS, TRC 2 a BA in foreign languages while TRC 11 notes "he is familiar with basic of coding.". Candidates also search for internship oppurtunities or tips for the beginners or enrich their portfolio.

TCs rarely search for internship oppurtunities or tips though.

Address

RumeliDE Journal of Language and Literature Studies

Osmanağa Mahallesi, Mürver Çiçeği Sokak, No:14/8

Kadıköy - ISTANBUL / TURKEY 34714

e-mail: editor@rumelide.com

phone: +90 5057958124, +90 2167730616 


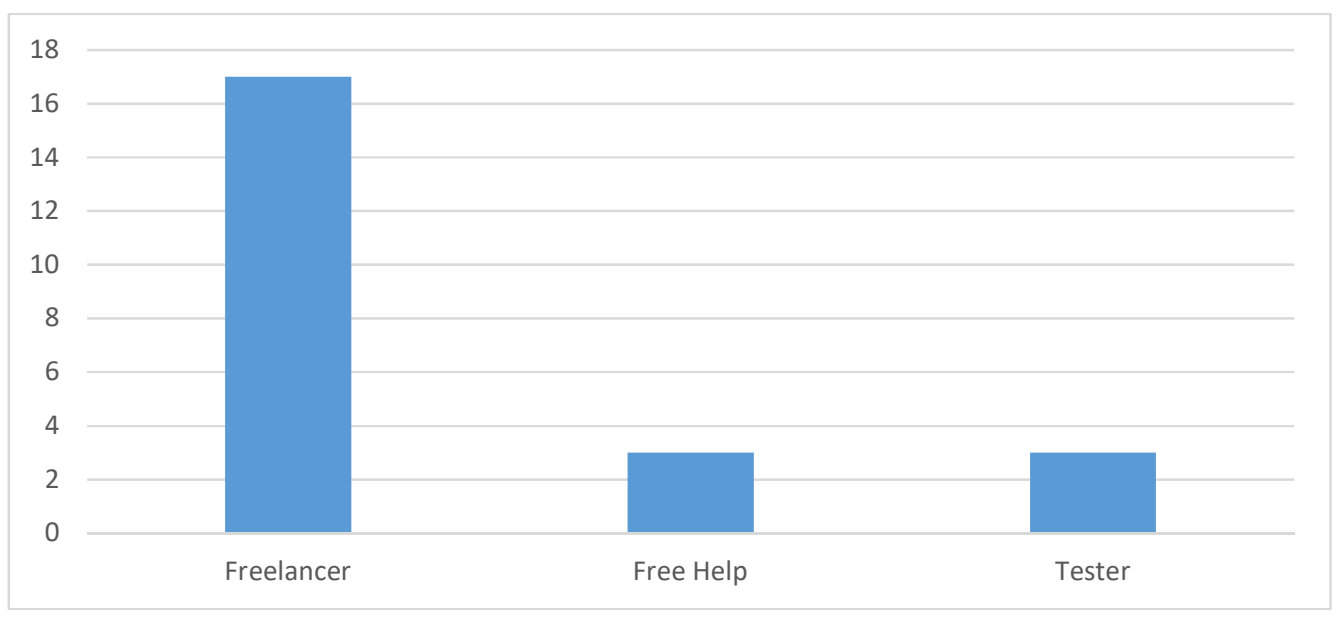

Figure 4 The posts by game developers classified according to content

As indicated in Figure 4, the vast majority of posts by game developers are to search for freelancers with proper qualities. The content of the posts cover language pair or the level of localization required, the scale of localization project, the genre or the structure of the game, confidentiality level (if any), the scale of the playtesting (if any), the tools required (if any). The nature of the posts by game developers indicate that a vast majority of developers search for not free labour but freelancers. A few cases cover exceptional information as in the case of a developer (DEV 9) who searches for free help: "Our very small game is looking for volunteers to help translate our game in different languages! It was built in a week by a few college students, so unfortunately we don't really have a means to compensate, very sorry! $\pi-\pi$ ", or another developer team (DEV 11) who translated their own project and search for free playtesting: "Hello, we are looking for volunteers who would like to playtest/proofread our localizations".

A unique case (DEV 6) is a member looking for a freelancer to translate their Steam page into Russian.

"Calling for help of the volunteer for playtesting" is common as well. DEV 21 marks "they are looking for volunteers who would like to playtest/proofread their localizations". Given the language command and gaming history or the members, the community may be seen as a convenient space to search for playtesting needs which would require enourmous amount of community support in any other way.

Adres
RumeliDE Dil ve Edebiyat Araşturmaları Dergisi Osmanağa Mahallesi, Mürver Çiçeği Sokak, No:14/8 Kadıköy - ISTANBUL / TÜRKIYE 34714 e-posta: editor@rumelide.com tel: +90 $5057958124,+902167730616$
Address

RumeliDE Journal of Language and Literature Studies

Osmanağa Mahallesi, Mürver Çiçeği Sokak, No:14/8

Kadıköy - ISTANBUL / TURKEY 34714

e-mail: editor@rumelide.com,

phone: +90 5057958124, +90 2167730616 


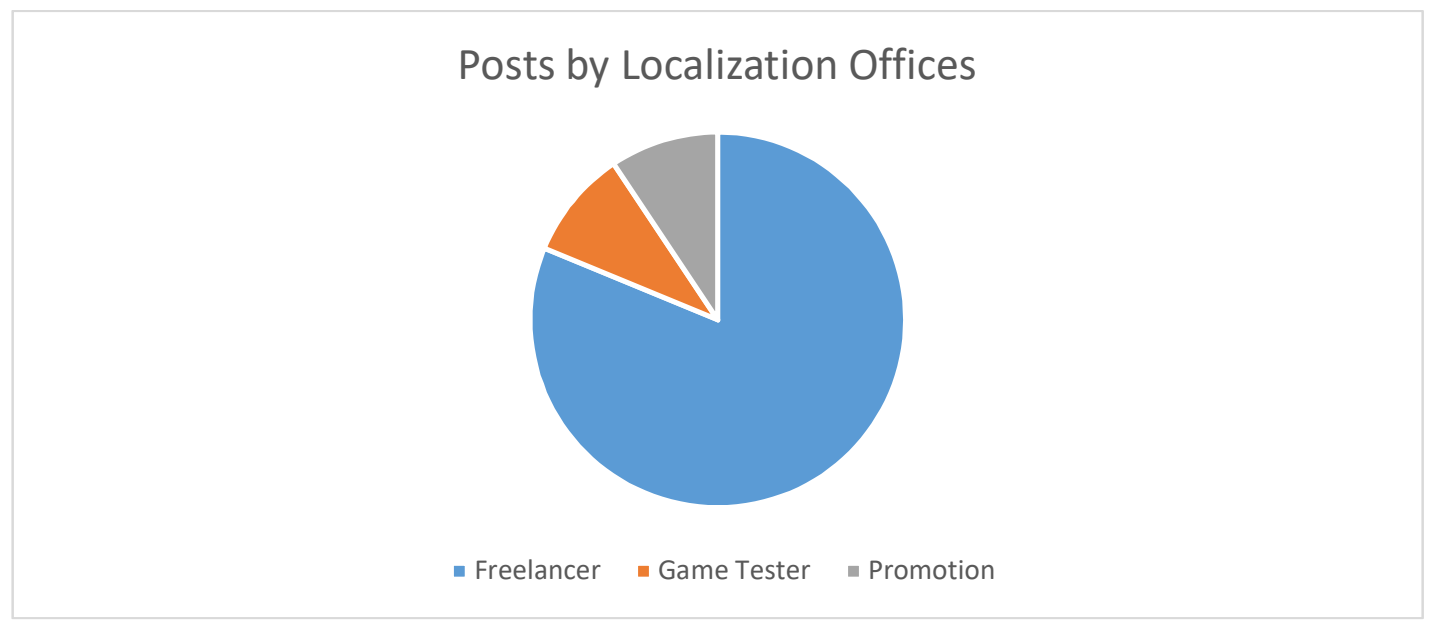

Figure 5 The posts by localization offices classified according to the content

The vast majority of posts by localization offices cover content on search for freelancers. The post on freelancer search cover language pair, qualifications required and information on the project (if any) as implied by Figure 5 .

The post cover language pairs Thai - Japanese, Korean- Japanese, Chinese- English, English - French, Brazilian Portuguese, Korean, Italian, Turkish, Russian, Polish, Portuguese, Indonesian, Thai, Traditional Chinese, Spanish Lat Am (Mexican). A few localization offices search for game testers in French, Italian, German, Spanish, Brazilian Portuguese. Their search for gamer translators is exceptionally underlined in the posts. For instance, LOC 19 notes that "this offer is perfect for you: video games are your passion.". A localization office (LOC) calls for MOBA players: "This offer is perfect for you:a- you are a MOBA games player". Another posts calls the interest of participants who "have a passion for mobile, pc or console games"

A final group of posts cover content by researchers. The number of the posts ( 3 posts) are relatively low compared to the other groups. The posts call for attention of the members. The researchers ask the members to participate in surveys in their posts.

\section{Discussion}

This paper focuses the lenses on the people who meet in a virtual community. According to the data gathered, the group serves as a hybrid space which is shaped by various actors. There are four main types of users/community members: translators and translator candidates, localization agencies, indie game developers and researchers. Each group has a unique set of demands and offers.

Translators are classified as "the practitioners of localization with former experience and portfolio". They may be called "professionals who search for paid positions". They offer paid services. Their posts cover information on their professional portfolio and their personal background in gaming (if any) and language pairs they work in.

Translator candidates are classifed often as "free labour providers" who wish to build up portfolio. They are to declare their interest in gaming, their passion and command of peculiar genres, their command of certain language pairs or their drive to have a career in localization industry. They pursue a prospective career in

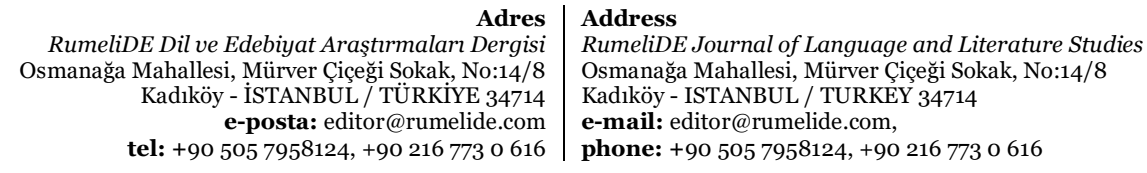


video game localization industry. Their posts cover their personal history of gaming, their passion for a specific genre or their drive to pursue a career in localization industry. The posts indicate that they demand to be visible so they can build up a portfolio for a prospective career.

Game developers are classified as professionals who search for free, cheaper or competent labour to compensate for the lack or limited capital allocated to localization. They are to announce their search for free help, limited scale localization, game testing or voicing needs or language check issues. Analysis of their posts indicates that game developers often search for freelancers or translator candidates who are actually competent in gaming or have a good command of a certain genre.

Localization agencies, classified as institutions that search for the freelancers for localization projects. They announce the position-specific language pairs and requirements for positions or certain genre- oriented positions.

Researchers are out-of-industry professionals who accept the group as a field of research. They attempt to acquire data for their prospective research projects.

The interaction between these groups shape "the nature" of the community. The community evolves into virtual space attached to the localization industry. The space serves as "a gathering hall" for localization offices that search for competent freelancers or game testers with a command of certain game genre who are currently out of current industry; as "a source of cheap or free localization - or peripheral- service" for indie game developers; as "a gateway into the localization industry" for the translator candidates and "a site of job search" for translators. This complex sphere serves as a field where experience, history of gaming, visibility in portfolio are exchanged. Thus, the community may be classified as a hybrid community bearing the traits of discussion or conversation communities - task- and goal-oriented communities with close ties to the offline world.

\section{Conclusion}

Indie games are small-budget games developed by a single person or a small group of developers. Due to the budget limitations and lack of human resources allocated to the localization, the developers may search for alternative pathways which also cover collaboration with freelancers, amateurs or candidate translators.

Such online communities serve as a sphere of collaboration and an extension of localization industry for indie game localization. They are alternative spaces where translators, translator candidates, game developers and localization agencies gather, they share technical or legal issues, they search for job or search for employees, they search or provide free - paid labour-help. They serve as alternative pathways of career in localization industry.

The interaction analyzed within scope of the current paper indicates:

a) The vast majority of the content may be classified as collaborative.

b)Translator, translator candidates, localization agencies and indie game developers gather in cyberspace through communities.

c) The online and offline interaction and collaboration- interaction is closely tied.

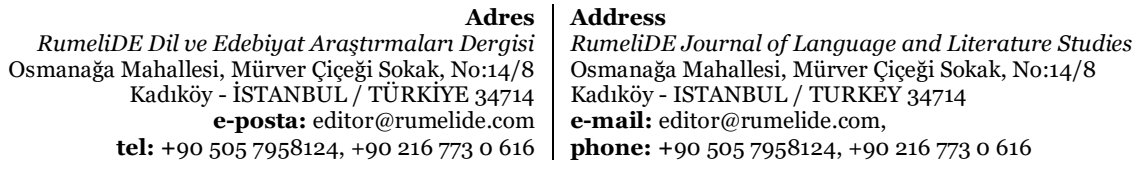


This research was limited with analysis of posts created in 6-month-period. Future research on online communities with a wider dataset or in different communities of translators is needed to reveal various aspects of interaction among localization industry, indie game developers and translators as each virtual space has its own dynamics and structure.

\section{Resources}

Alan R. D., Sridar K. P. \& Vijaya L. N. (1998). Lessons from the Early Adopters of Web Groupware. Journal of Management Information Systems, (14)4. 65-86. doi: 10.1080/07421222.1998.11518186.

Armstrong, A., \& Hagel, J. (2000). The real value of online communities. In Lesser E.L,Fontaine M.A.\& Slusher, J.A. (Eds.) Knowledge and communities, 85-95.

Berthouzoz, M. (2019) Localization Choices in Indie Games : A Study on the Influencing Factors. [Unpublished Master Thesis] Univ. Genève.

Burnett, G. (2000). Information exchange in virtual communities: A typology. Information Research: An International Electronic Journal, 5(4).

Burnett, G. \& Buerkle, H. (2004). Information Exchange in Virtual Communities: A Comparative Study. Journal of Computer-Mediated Communication,(9)00-00. https://doi.org/10.1111/j.10836101.2004.tb00286.x.

Consalvo, M. (2012). A Localizations Shop Tale: Bringing an Independent Japanese Role- playing Game to North America. In Delwiche, A.A. and Henderson, J.J., (Eds.) The Participatory Cultures Handbook. Routledge. 59-70.

Czarnota, J. (2018) Co-Creation, Innovation and New Service Development The Case of the Videogames Industry. Routledge.

Dickinson, A. M., \& Km, M. A. S. (2002). Knowledge Sharing in Cyberspace: Virtual Knowledge Communities. Lecture Notes in Computer Science. 457-471. doi:10.1007/3-540-36277-0_41.

Driskell, R. B., \& Lyon, L. (2002). Are Virtual Communities True Communities? Examining the Environments and Elements of Community. City and Community, 1(4). 373-390. doi:10.1111/1540-6040.00031.

Fiadotau, M. (2018) Indie Game. Lee, N. (ed.). Encyclopedia of Computer Graphics and Games. Springer. doi:10.1007/978-3-319-08234-9_188-1

Freeman, G. \& McNeese, N.J. (2019) Exploring Indie Game Development: Team Practices and Social Experiences in A Creativity-Centric Technology Community.Comput Supported Coop Work 28, 723748. doi:10.1007/s10606-019-09348-x.

Garda, M.B. \& Grabarczyk, P. (2016) Is every indie game independent? Towards the concept of independent game, Game Studies, 16(1). http://gamestudies.org/1601/articles/gardagrabarczyk

Guevara-Villalobos O. (2011) Cultures Of Independent Game Production: Examining The Relationship Between Community and Labour. DiGRA '11 - Proceedings of the 2011 DiGRA International Conference: Think Design Play DiGRA/Utrecht School of the Arts. January, 2011 (6).

Hector P. (2003) From Pong to Planet Quake: Post-Industrial Transitions from Leisure to Work, Information, Communication \& Society, 6(4), 593-607. doi:10.1080/1369118032000163277.

Howard, A. \& Mawyer, A. (2015) Ethnography in the Digital Age. Scott, R.A. \& Kosslyn, S. M. (Eds.) Emerging Trends in the Social and Behavioral Sciences. doi:10.1002/9781118900772.etrds0119.

Indie Game Localization (11 July, 2014) About This Group [Indie Game Localization] Facebook. Retrieved 04 January, 2021 from https://www.facebook.com/groups/indiegamelocalization/about

Johnson, C.M. (2001) A Survey of the Current Research on Online Communities of Practice. Internet and Higher Education, (4) 45 - 60.

Jong S.T. (2019) Netnography: Researching Online Populations. Liamputtong P. (Eds) Handbook of Research Methods in Health Social Sciences. Springer. doi:10.1007/978-981-10-5251-4_17.

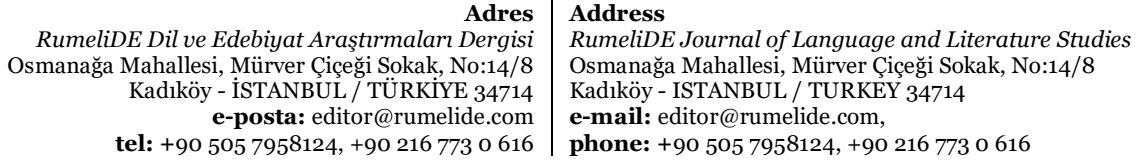


Karagöz, S. (2019) Amateurs, Experts, Explorers: Video Game Localization Practices in Turkey. [Unpublished Ph.D. Thesis]. Yıldiz Technical University.

Karagöz, S. \& Bogenç Demirel E. (2019) Oyun Yerelleștirmesi Alanında Oyuncu Müdahilliği: Türkiye'de Oyun Yerelleștirme Alanı Örneğinde Netnografik Bir İnceleme. Frankofoni. 2019 ( 35) 73- 85.

Katayoon A. \& Mahboobeh Z. (2021). A netnographic exploration of Iranian videogame players translation needs: the case of in-game texts. The Translator. doi:10.1080/13556509.2021.1880536.

Kozinets, R V. (2010) Netnography: Doing Ethnographic Research Online. London. Sage Publications.

Lipkin, N. (2013) Examining Indie's Independence: The Meaning of "Indie" Games, the Politics of Production, and Mainstream Co-optation. Loading... The Journal of the Canadian Game Studies Association, 7(11): 8-24.

Martin, C. B., \& Deuze, M. (2009). The Independent Production of Culture: A Digital Games Case Study. Games and Culture, 4(3), 276-295. doi:10.1177/1555412009339732.

Mangiron, C. (2017) “Research in Game Localisation: An Overview.” The Journal of Internationalization and Localization, 4 (2), 74-99. doi:10.1075/jial.00003.man.

Mesch, G. S. (2018) Online Communities. In Cnaan, R. A., \& Milofsky, C. (eds) (2018). Handbook of Community Movements and Local Organizations in the 21st Century. Springer eBooks.

O'Hagan, M. and Heather C. (2016) "Game localization research and translation studies: Loss and gain under an interdisciplinary lens." In Gambier Y. \& van Doorslaer. L. (Eds) Border Crossings: Translation Studies and Other Disciplines. John Benjamins. 309-330.

Porter, E. (2004). A typology of virtual communities: A multi-disciplinary foundation for future research. Journal of Computer-Mediated Communication. 10(1). doi:10.1111/j.1083-6101.2004.tb00228.x.

Ruffino, P. (2013) Narratives of Independent Production in Video Game Culture. Loading... The Journal of the Canadian Game Studies Association, 7(11). 106-121.

Simon, B. (2013) „Indie Eh? Some Kind of Game Studies.“, Loading... The Journal of the Canadian Game Studies Association, 7(11). 1-7.

Stanoevska-Slabeva, K. (2002) Toward a Community-Oriented Design of Internet Platforms, International Journal of Electronic Commerce, 6(3), 71-95, doi:10.1080/10864415.2002.11044244.

Süter-Görgüler, Z. (2016) Yeni Toplumsallıklar Etrafında Yükselen Çeviri Pratikleri. Türkiye'de Tara-Çeviri İçeriklerinin(Manga) Dolaşımı ve Netnografik Çözümlemeler. [Unpublished Ph.D. Thesis]. Yıldız Technical University.

Toftedahl, M., Backlund, P., Engström, H. (2018) Localization from an Indie Game Production Perspective: Why, When and How?, DiGRA '18 - Proceedings of the 2018 DiGRA International Conference: The Game Is the Message, Presented at the DiGRA 2018 - "The Game is the Message", Turin, Italy, urn.kb.se/resolve?urn=urn:nbn:se:his:diva-16133.

Wellman, B., \& Gulia, M. (1999). Net surfers don't ride alone: Virtual communities as communities. Wellman, B. (Ed). Networks in the Global Village. Boulder, CO. Westview. 331-66.

Yoccoz, D. Is It Worth Localizing An Indie Game? https://www.leveluptranslation.com/single-post/is-itworth-localizing-an-indie-game, 06. 10.2017.

Adres
RumeliDE Dil ve Edebiyat Araşturmaları Dergisi Osmanağa Mahallesi, Mürver Çiçeği Sokak, No:14/8 Kadıköy - ISTANBUL / TÜRKIYE 34714 e-posta: editor@rumelide.com tel: +90 $5057958124,+902167730616$
Address

RumeliDE Journal of Language and Literature Studies

Osmanağa Mahallesi, Mürver Çiçeği Sokak, No:14/8

Kadıköy - ISTANBUL / TURKEY 34714

e-mail: editor@rumelide.com,

phone: +90 $5057958124,+902167730616$ 